\title{
Phylogeny of Sporeforming Members of the Order Actinomycetales
}

\author{
ERKO STACKEBRANDT,* WOLFGANG LUDWIG, ELKE SEEWALDT, AND KARL-HEINZ \\ SCHLEIFER
}

Lehrstuhl für Mikrobiologie, Technische Universität München, 8000 Munich 2, Federal Republic of Germany

\begin{abstract}
Representatives from various genera of the order Actinomycetales were investigated by comparative cataloging of their $16 \mathrm{~S}$ ribosomal ribonucleic acids to establish their phylogenetic relationships. Members of Actinoplanes, Ampullariella, Dactylosporangium, and Micromonospora form one cluster that is peripherally related to the cluster defined by members of Mycobacterium, Nocardia, and Rhodococcus. Streptomyces griseus and strains of Chainia, Kitasatoa, Streptoverticillium, Microellobosporia, and Elytrosporangium are phylogenetically closely related, whereas Streptosporangium roseum is more distantly related to this cluster. Thermomonospora curvata and Geodermatophilus obscurus represent individual clusters. Promicromonospora citrea is a member of the Arthrobacter-Micrococcus-Cellulomonas line of descent. This grouping of organisms is highly supported not only by data from deoxyribonucleic acid-deoxyribonucleic acid homology studies and deoxyribonucleic acid-ribosomal ribonucleic acid cistron similarity studies but also by several common biochemical characteristics of proven taxonomic value.
\end{abstract}

In the first part of our investigation of the molecular genetic relatedness of sporeforming members of the order Actinomycetales (19), which was based on nucleic acid reassociation studies, we concluded that most of these organisms can be grouped into three major clusters. The first of these clusters includes members of Actinoplanes, Ampullariella, Amorphosporangium, Dactylosporangium, and Micromonospora, the second cluster contains Streptosporangium roseum, Planobispora longispora, and Planomonospora parontospora, and the third cluster contains representatives of various genera of the Streptomycetaceae (i.e., Streptomyces, Kitasatoa, Chainia, Streptoverticillium, Elytrosporangium, and Actinosporangium).

Deoxyribonucleic acid (DNA)-DNA reassociation studies have shown that strains of each of these clusters are closely to moderately related. DNA-ribosomal ribonucleic acid (rRNA) cistron similarity experiments have supported this finding, and, in addition, the data obtained did not reveal any specifically closer relationship between any two of the three clusters.

The most successful method for unraveling the phylogenetic relatedness of higher taxa is comparative analysis of the ribonuclease $T_{1}$ resistant oligonucleotides of $16 \mathrm{~S}$ rRNAs $(4,5$, 18). More than 250 species of bacteria have already been investigated by this method, and the resulting phylogenetic tree is an impressive demonstration of its usefulness $(5,18)$. Analysis of $16 \mathrm{~S}$ rRNAs allows workers to determine the degree of relatedness of distantly related organisms and also provides a key to phylogenetic classification of bacteria (1).

Only a few representatives of the order Actinomycetales have been investigated with this method previously $(5,16,17)$. Extending these studies, we not only included species of the homology clusters defined previously (19), but also determined the degree of relatedness between these organisms and strains of Geodermatophilus obscurus, Nocardia asteroides, Thermomonospora curvata, Promicromonospora citrea, and coryneform bacteria.

\section{MATERIALS AND METHODS}

All of the organisms investigated in this study are listed in Table 1 . Information concerning the sources of these strains is also presented in Table 1. Except for Thermomonospora curvata DSM $43183^{\mathrm{T}}$ (type strain), all organisms were grown aerobically at $30^{\circ} \mathrm{C}$ in $300 \mathrm{ml}$ of yeast extract-peptone-sucrose broth as described previously (19). The medium for Thermomonospora curvata DSM $43183^{\mathrm{T}}$ was prepared as follows. A $20-\mathrm{g}$ portion of rolled oats was boiled for $20 \mathrm{~min}$ and filtered through Whatman no. 1 filter paper. The resulting filtrate was made up to $1,000 \mathrm{ml}, 1 \mathrm{ml}$ of a trace element solution was added $\left(\mathrm{FeSO}_{4} \cdot 7 \mathrm{H}_{2} \mathrm{O}, 0.1 \mathrm{~g}\right.$; $\mathrm{MnCl}_{2} \cdot 4 \mathrm{H}_{2} \mathrm{O}, 0.1 \mathrm{~g} ; \mathrm{ZnSO}_{4} \cdot 7 \mathrm{H}_{2} \mathrm{O}, 0.1 \mathrm{~g}$; distilled water, $100 \mathrm{ml}$ ), and the $\mathrm{pH}$ was adjusted to 7.2. Thermomonospora curvata DSM $43183^{\mathrm{T}}$ was grown aerobically in $500 \mathrm{ml}$ of this medium at $50^{\circ} \mathrm{C}$. The purity of each culture was checked microscopically. Bacteria were harvested after 2 to 4 days of growth by filtration through Whatman no. 1 filter paper. 
TABLE 1. Binary comparisons among the $16 \mathrm{~S}$ rRNA catalogs $\left(S_{\mathrm{AB}} \text { values }\right)^{a}$

\begin{tabular}{|c|c|c|c|c|c|c|c|c|c|}
\hline \multirow{2}{*}{$\begin{array}{c}\text { Serial } \\
\text { no. }\end{array}$} & \multirow{2}{*}{ Organism $^{b}$} & \multicolumn{8}{|c|}{$S_{\mathrm{AB}}$ values compared with the following strains: } \\
\hline & & 1 & 2 & 3 & 4 & 5 & 6 & 7 & 8 \\
\hline 1 & Ampullariella regularis $\mathrm{DSM} 43151^{\mathrm{T}}$ & 1.00 & & & & & & & \\
\hline 2 & Actinoplanes philippinensis DSM 43019 & 0.80 & 1.00 & & & & & & \\
\hline 3 & Dactylosporangium aurantiacum NRRL B-8111 & 0.71 & 0.72 & 1.00 & & & & & \\
\hline 4 & Micromonospora chalcea NRRL B-2344 & 0.75 & 0.75 & 0.76 & 1.00 & & & & \\
\hline 5 & Streptomyces griseus Ensign 1947 & 0.46 & 0.50 & 0.51 & 0.49 & 1.00 & & & \\
\hline 6 & Kitasatoa kauaiensis DSM $43360^{\mathrm{T}}$ & 0.46 & 0.50 & 0.53 & 0.48 & 0.87 & 1.00 & & \\
\hline 7 & Chainia antibiotica DSM $43032^{\mathrm{T}}$ & 0.47 & 0.49 & 0.52 & 0.51 & 0.70 & 0.71 & 1.00 & \\
\hline 8 & Streptoverticillium baldaccii DSM $40845^{\mathrm{T}}$ & 0.46 & 0.48 & 0.53 & 0.51 & 0.82 & 0.82 & 0.75 & 1.00 \\
\hline 9 & Microellobosporia cinerea DSM $43033^{\mathrm{T}}$ & 0.47 & 0.48 & 0.49 & 0.47 & 0.78 & 0.79 & 0.78 & 0.76 \\
\hline 10 & Elytrosporangium brasiliense DSM $43159^{\mathrm{T}}$ & 0.47 & 0.50 & 0.52 & 0.50 & 0.69 & 0.70 & 0.82 & 0.68 \\
\hline 11 & Streptosporangium roseum DSM $43021^{\mathrm{T}}$ & 0.53 & 0.54 & 0.55 & 0.51 & 0.64 & 0.66 & 0.64 & 0.63 \\
\hline 12 & Thermomonospora curvata DSM $43183^{\mathrm{T}}$ & 0.45 & 0.44 & 0.44 & 0.48 & 0.51 & 0.53 & 0.54 & 0.52 \\
\hline 13 & Geodermatophilus obscurus DSM $43160^{\mathrm{T}}$ & 0.50 & 0.49 & 0.51 & 0.50 & 0.52 & 0.56 & 0.53 & 0.52 \\
\hline 14 & Arthrobacter globiformis DSM $20124^{\mathrm{T}}$ & 0.53 & 0.58 & 0.56 & 0.52 & 0.57 & 0.59 & 0.59 & 0.55 \\
\hline 15 & Oerskovia turbata ATCC $25835^{\mathrm{T}}$ & 0.54 & 0.56 & 0.59 & 0.58 & 0.54 & 0.55 & 0.58 & 0.54 \\
\hline 16 & Cellulomonas flavigena DSM $20109^{\mathrm{T}}$ & 0.46 & 0.49 & 0.53 & 0.52 & 0.51 & 0.52 & 0.56 & 0.50 \\
\hline 17 & Promicromonospora citrea DSM $43110^{\mathrm{T}}$ & 0.51 & 0.52 & 0.55 & 0.54 & 0.59 & 0.62 & 0.60 & 0.58 \\
\hline 18 & Corynebacterium diphtheriae ATCC 11913 & 0.45 & 0.52 & 0.53 & 0.48 & 0.50 & 0.50 & 0.49 & 0.47 \\
\hline 19 & Mycobacterium phlei ATCC $11758^{\mathrm{T}}$ & 0.53 & 0.59 & 0.62 & 0.57 & 0.51 & 0.52 & 0.51 & 0.48 \\
\hline 20 & Nocardia asteroides DSM 43005 & 0.60 & 0.65 & 0.62 & 0.58 & 0.58 & 0.61 & 0.64 & 0.62 \\
\hline 21 & Thermoactinomyces vulgaris $\mathrm{P} 12$ & 0.24 & 0.26 & 0.25 & 0.31 & 0.31 & 0.32 & 0.36 & 0.31 \\
\hline 22 & Bacillus subtilis ATCC 15563 & 0.24 & 0.29 & 0.30 & 0.26 & 0.31 & 0.33 & 0.37 & 0.34 \\
\hline 23 & Escherichia coli B-236 & 0.25 & 0.29 & 0.28 & 0.28 & 0.24 & 0.24 & 0.29 & 0.25 \\
\hline
\end{tabular}

a When strains within groups were compared, the following DNA-DNA homology values were obtained: for the group that included strains 1 through 4,18 to $28 \%$; for the group that included strains 5 through 10,28 to $40 \%$; for the group that included strains 15 and 16, 20\%. When comparisons were made between groups, the following DNA-DNA homology values were obtained $(14,19)$ : the group that included strains 1 through 4 compared with the group that included strains 5 through 10,6 to $12 \%$; the group that included strains 1 through 4 compared with strain 11, 11 to $12 \%$; the group that included strains 5 through 10 compared with strain 11,10 to $13 \%$. Homology values for strains 12 and 13 and for strains 17 through 23 were not determined.

${ }^{b}$ DSM, Deutsche Sammlung von Microorganismen, Göttingen, Federal Republic of Germany; ATCC, American Type Culture Collection, Rockville, Md.; NRRL, National Regional Research Laboratory Culture Collection, Agricultural Research Service, Peoria, Ill. Streptomyces griseus Ensign 1947 was kindly provided by Jerald C. Ensign, University of Wisconsin, Madison.

We isolated $16 \mathrm{~S}$ rRNAs by breaking cells in a French press and then subjecting the phenolized lysate to one-dimensional slab gel electrophoresis, as described previously (16). Digestion of the rRNA with ribonuclease $T_{1}$ (Calbiochem-Behring, La Jolla, Calif.), 3 '-end dephosphorylation of the resulting oligonucleotides, 5' labeling with polynucleotide kinase (Boehringer, Mannheim, West Germany) and $1 \mathrm{mCi}$ of $\gamma-{ }^{32}$ P-labeled adenosine triphosphate (Amersham, Braunschweig, West Germany), removal of excess $\gamma$ ${ }^{32}$ P-labeled adenosine triphosphate with Apyrase (Sigma, Munich, West Germany), fingerprinting of the oligonucleotides, and sequence determination were done by the methods of Stackebrandt et al. (16). Binary matching coefficients $\left(S_{\mathrm{AB}}\right)$ were calculated as described by Fox et al. (4).

\section{RESULTS}

Table 2 lists the oligonucleotide catalogs for the strains investigated in this study, together with the catalogs for sporeforming members of the order Actinomycetales that have been published previously $(16,17)$. The $S_{\mathrm{AB}}$ values for the strains, various other gram-positive eubacteria, and Escherichia coli and the resulting dendrogram of relationships are shown in Table 1 and Fig. 1, respectively. More detailed relationships within the clusters containing representatives of the genera Corynebacterium and Nocardia (17) and representatives of the genera Arthrobacter, Cellulomonas, Microbacterium, 
TABLE 1-Continued

\begin{tabular}{|c|c|c|c|c|c|c|c|c|c|c|c|c|c|c|}
\hline \multicolumn{15}{|c|}{$S_{\mathrm{AB}}$ values compared with the following strains: } \\
\hline 9 & 10 & 11 & 12 & 13 & 14 & 15 & 16 & 17 & 18 & 19 & 20 & 21 & 22 & 23 \\
\hline
\end{tabular}

\begin{tabular}{|c|c|c|c|c|c|c|c|c|c|c|c|c|c|c|}
\hline $\begin{array}{l}1.00 \\
0.71\end{array}$ & 1.00 & & & & & & & & & & & & & \\
\hline 0.65 & 0.59 & 1.00 & & & & & & & & & & & & \\
\hline 0.52 & 0.49 & 0.58 & 1.00 & & & & & & & & & & & \\
\hline 0.54 & 0.52 & 0.57 & 0.56 & 1.00 & & & & & & & & & & \\
\hline 0.56 & 0.59 & 0.54 & 0.52 & 0.53 & 1.00 & & & & & & & & & \\
\hline 0.53 & 0.57 & 0.56 & 0.47 & 0.52 & 0.67 & 1.00 & & & & & & & & \\
\hline 0.51 & 0.53 & 0.50 & 0.47 & 0.49 & 0.66 & 0.71 & 1.00 & & & & & & & \\
\hline 0.59 & 0.57 & 0.59 & 0.50 & 0.58 & 0.63 & 0.66 & 0.63 & 1.00 & & & & & & \\
\hline 0.48 & 0.48 & 0.47 & 0.40 & 0.43 & 0.57 & 0.53 & 0.50 & 0.54 & 1.00 & & & & & \\
\hline 0.49 & 0.50 & 0.48 & 0.43 & 0.43 & 0.57 & 0.51 & 0.48 & 0.53 & 0.59 & 1.00 & & & & \\
\hline 0.59 & 0.56 & 0.59 & 0.49 & 0.41 & 0.56 & 0.55 & 0.49 & 0.62 & 0.57 & 0.69 & 1.00 & & & \\
\hline 0.36 & 0.32 & 0.34 & 0.35 & 0.33 & 0.32 & 0.30 & 0.29 & 0.34 & 0.28 & 0.26 & 0.30 & 1.00 & & \\
\hline 0.35 & 0.34 & 0.35 & 0.33 & 0.33 & 0.32 & 0.31 & 0.29 & 0.36 & 0.31 & 0.29 & 0.34 & 0.52 & 1.00 & \\
\hline 0.24 & 0.26 & 0.23 & 0.21 & 0.21 & 0.24 & 0.20 & 0.23 & 0.22 & 0.26 & 0.28 & 0.30 & 0.23 & 0.26 & 1.00 \\
\hline
\end{tabular}

and Brevibacterium (15) have been published previously.

The sporeforming members of the order Actinomycetales investigated occurred in four lines of descent within the major subgroup of grampositive bacteria exhibiting high DNA guanineplus-cytosine contents ( $\leq 55 \mathrm{~mol} \%)$. These lines were separated from each other by $S_{\mathrm{AB}}$ values of about 0.52 (Fig. 1).

Promicromonospora citrea DSM $43110^{\mathrm{T}}$, a highly pleomorphic organism, was found to be a member of a fifth line, which contained arthrobacters, cellulomonads, and oerskovias, as well as brevibacteria, micrococci, and microbacteria and their relatives (data not shown). Members of this line are related to strains in the other four lines of descent at an average $S_{\mathrm{AB}}$ value of 0.52 .

\section{DISCUSSION}

The close phylogenetic relationship which we found among certain species of different genera (e.g., those in the Streptomyces griseus subcluster and those in the Actinoplanes philippinensis cluster) is in accord with data obtained from DNA-DNA reassociation studies (Table 1) and with results of DNA-rRNA cistron similarity studies (19). Strains in these clusters share DNA homology values of $18 \%$ or greater, and the $\Delta T_{m(e)}$ values of the DNA-rRNA hybrids are $7^{\circ} \mathrm{C}$ or lower. On the other hand, the DNA homology values between representatives of the individual clusters are all $13 \%$ or less, whereas the $\Delta T_{m(e)}$ values are $10^{\circ} \mathrm{C}$ or higher.

The phylogenetic grouping of organisms reported here is strongly supported by common characters of proven taxonomic value (e.g., the chemical composition of the peptidoglycan, the sugar composition of the cell walls, and the lipid composition of the cells). All strains of the Actinoplanes philippinensis cluster exhibit peptidoglycan of the meso-diaminopimelic acid type (variation A1 $\gamma$ according to Schleifer and Kandler [13]). A portion of the diaminopimelic acid residues are hydroxylated. In contrast to other representatives of the order Actinomycetales, alanine is replaced by glycine in position 1 of the peptide subunit of the peptidoglycan (7); this may be a valuable chemotaxonomic character. All members of the Actinoplanes philippinensis cluster contain xylose as a characteristic whole-cell sugar $(8,11)$. The cellular fatty acids 
TABLE 2. Oligonucleotide catalogs ${ }^{a}$

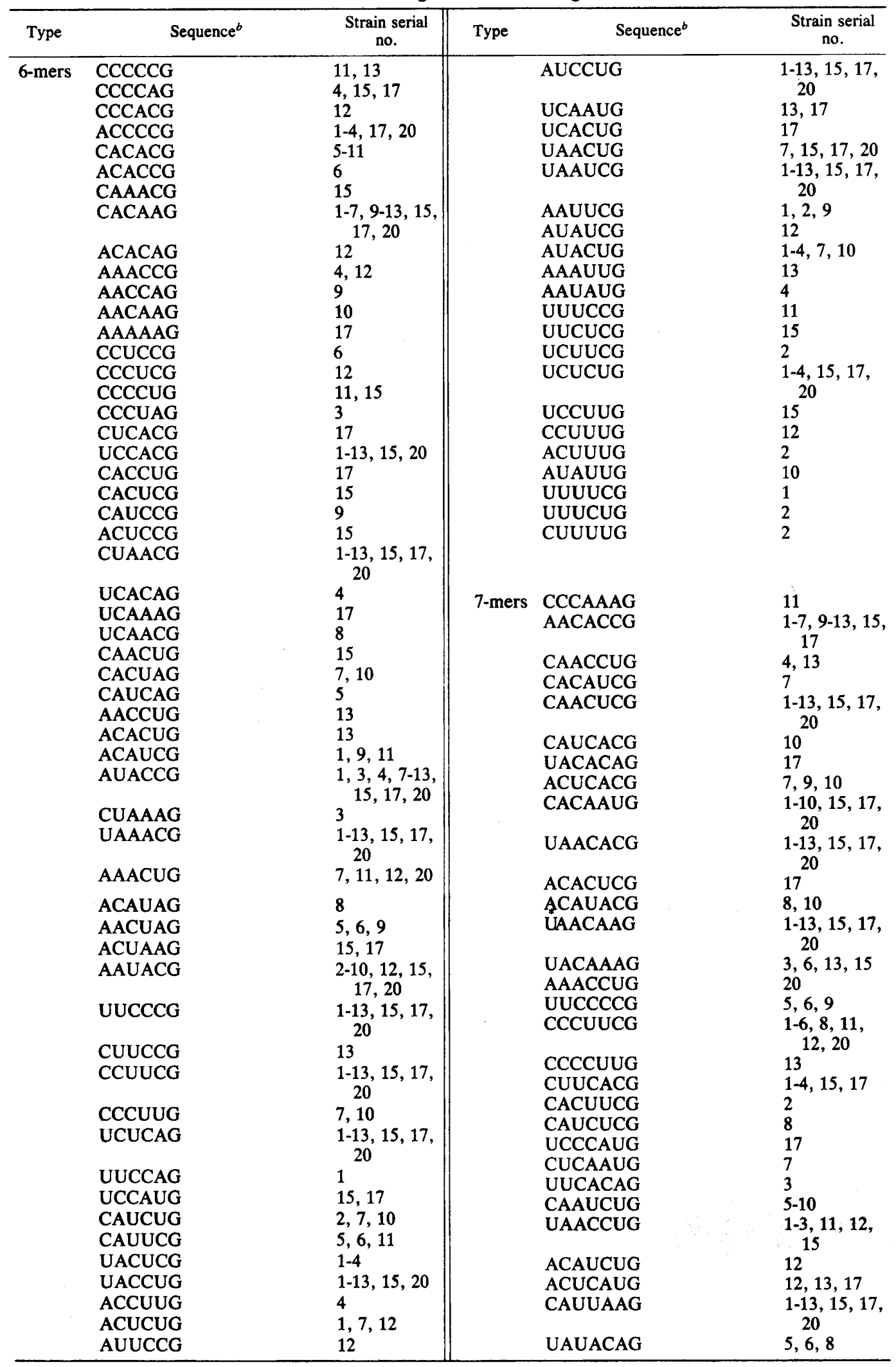


TABLE 2-Continued

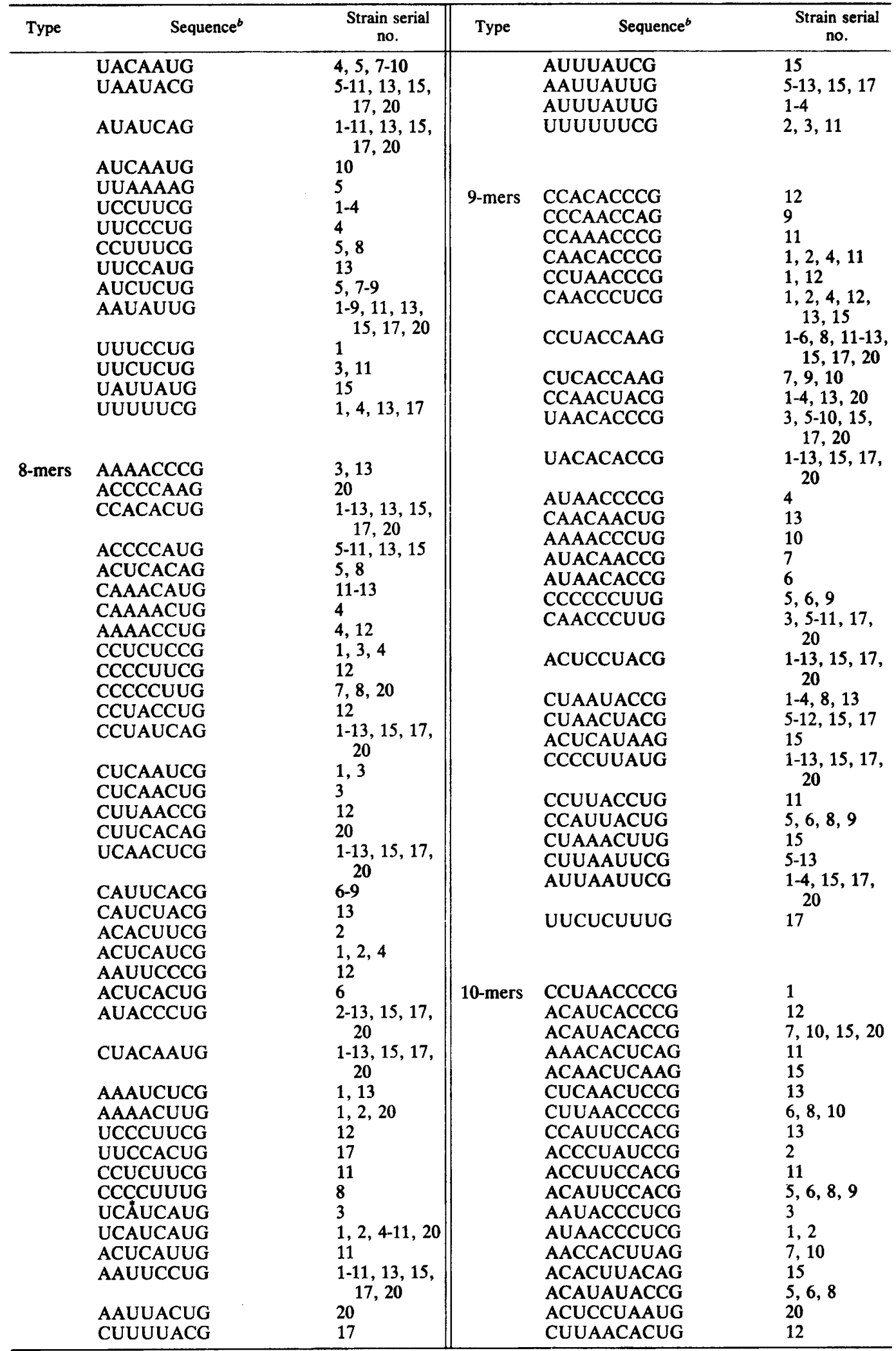


TABLE 2-Continued

\begin{tabular}{|c|c|c|c|c|c|}
\hline Type & Sequence $^{b}$ & $\begin{array}{l}\text { Strain serial } \\
\text { no. }\end{array}$ & Type & Sequence $^{b}$ & $\begin{array}{c}\text { Strain serial } \\
\text { no. }\end{array}$ \\
\hline \multirow{18}{*}{ 11-mers } & UCUAAUACCG & $5-12,17,20$ & \multirow{18}{*}{ 13-mers } & AAUCUCAAAAAG & $5-10$ \\
\hline & CUCAACUUAG & & & CCUAACCCCUUG & 2,20 \\
\hline & UUCUUACACG & 12 & & CCCCAAACUUUG & 1 \\
\hline & UCUAAUACUG & 15 & & AACCUUACCUAG & 13 \\
\hline & & & & AAUCCCUUAAAG & 20 \\
\hline & & & & CCCUUCACUUAG & 17 \\
\hline & CUCAACCCCAG & 4 & & CCCUUCACUCUG & $5,6,8$ \\
\hline & CCCAACCCUUG & $3,4,7,8,15$ & & CAACUCUCUUCG & 9 \\
\hline & AAAUCUCACAG & & & AAUAUUACUUAG & 1 \\
\hline & AUAACUCCAAG & 13 & & & \\
\hline & CUUCACACAUG & 20 & & & \\
\hline & CUCAUUCCACG & 15 & & CUAAAACUCAAAG & $1-13,15,17$ \\
\hline & ACCACUUACUG & & & & \\
\hline & AACCUUACCUG & $1-4,20$ & & UCAAAUCAUCAUG & $13,15,17$ \\
\hline & \multirow[t]{2}{*}{ CUUAACACAUG } & $1-13,15,17$ & & UAAACCUCUUUCG & 3 \\
\hline & & 20 & & AUAUUCAUUCUCG & 3 \\
\hline & CUUAACUCCAG & 11 & & UUAAAUAUUUUUG & 12 \\
\hline & AUAACACUCUG & 5 & & & \\
\hline \multirow{6}{*}{ 12-mers } & r & & \multirow{4}{*}{ 14-mers } & \multirow{3}{*}{ UAAACCUCUUUCAG } & \multirow{3}{*}{$\begin{array}{l}1,2,5-11 \\
13,15,17 \\
20\end{array}$} \\
\hline & CUCAACCCCAAG & $1,2,20$ & & & \\
\hline & AAUCCCAAAAAG & $\begin{array}{c}1-4,11,13 \\
15,17\end{array}$ & & & \\
\hline & CCCUCCACUCCG & & & & \\
\hline & CCCAACCCCUUG & $\begin{array}{l}5,6,10,13, \\
17\end{array}$ & 15-mers & AUACAACCACUACAG & 10 \\
\hline & $\begin{array}{l}\text { CAACAUUACACG } \\
\text { AACCUUACCAAG } \\
\text { AAUCCCUAAAAG }\end{array}$ & $\begin{array}{l}7,10 \\
5-12,15,17 \\
12\end{array}$ & 3 ' end & AUCACCUCCUUUCU $_{\mathrm{OH}}$ & $\begin{array}{l}1-13,15,17 \\
20\end{array}$ \\
\hline
\end{tabular}

${ }^{a}$ See Table 1 for strain serial numbers. The oligonucleotide catalogs of strains 3 through 5 have been published previously (17).

$b$ The asterisks indicate modified nucleotides.

of these strains include iso and anteiso branched acids together with large amounts of unsaturated fatty acids (8), and the major menaquinone of these organisms is of the MK9 (H4) type (9).

All members of the Streptomyces griseus subcluster contain LL-diaminopimelic acid and glycine in their cell walls, but unlike members of the Actinoplanes philippinensis cluster, glycine is involved in the cross-linkage of the peptide subunits, with alanine in position 1 (peptidoglycan variation $A 3 \gamma$ according to Schleifer and Kandler [13]). No member of this cluster contains sugars of diagnostic value (11). The cellular fatty acids of these strains are composed only of iso and anteiso branched acids, and their menaquinones are predominantly of the MK9 (H8) and MK9 (H6) types (9). The close relatedness which we found among species from different genera of the family Streptomycetaceae is further corroborated by the results of phage typing experiments; polyvalent Streptomyces phages attack strains of the genera Streptomyces, Chainia, Kitasatoa, Streptoverticillium, Elytrosporangium, and Microellobosporia (12). Planobispora longispora DSM $43041^{\mathrm{T}}$ and Planomon- ospora parontospora DSM $43177^{\mathrm{T}}$ are related to Streptosporangium roseum DSM $43021^{\mathrm{T}}$ by DNA reassociation values of 38 and $33 \%$, respectively (19). Members of this subcluster share a peptidoglycan of the A1 $\gamma$ variation (13). The peptidoglycan of these strains does not contain glycine (13), madurose is the whole-cell sugar (11), and all members of this subcluster synthesize 10-methyl branched and iso branched cellular fatty acids (8).

Thermomonospora curvata and Geodermatophilus obscurus show a low relationship to each other and are distinct from all other members of the order Actinomycetales. Thermomonospora curvata is not as closely related to Thermoactinomyces vulgaris (Fig. 1) as current taxonomy (3, 6) may indicate. The previous report of a close relationship between Geodermatophilus obscurus and Mycobacterium phlei, with an $S_{\mathrm{AB}}$ value of $0.78(17)$, is in error; although it has not been definitely determined, the data reveal that the strain used in the previous study, Geodermatophilus obscurus Ishiguro 22-28, was mislabeled and cannot be regarded as a strain of Geodermatophilus obscurus. 


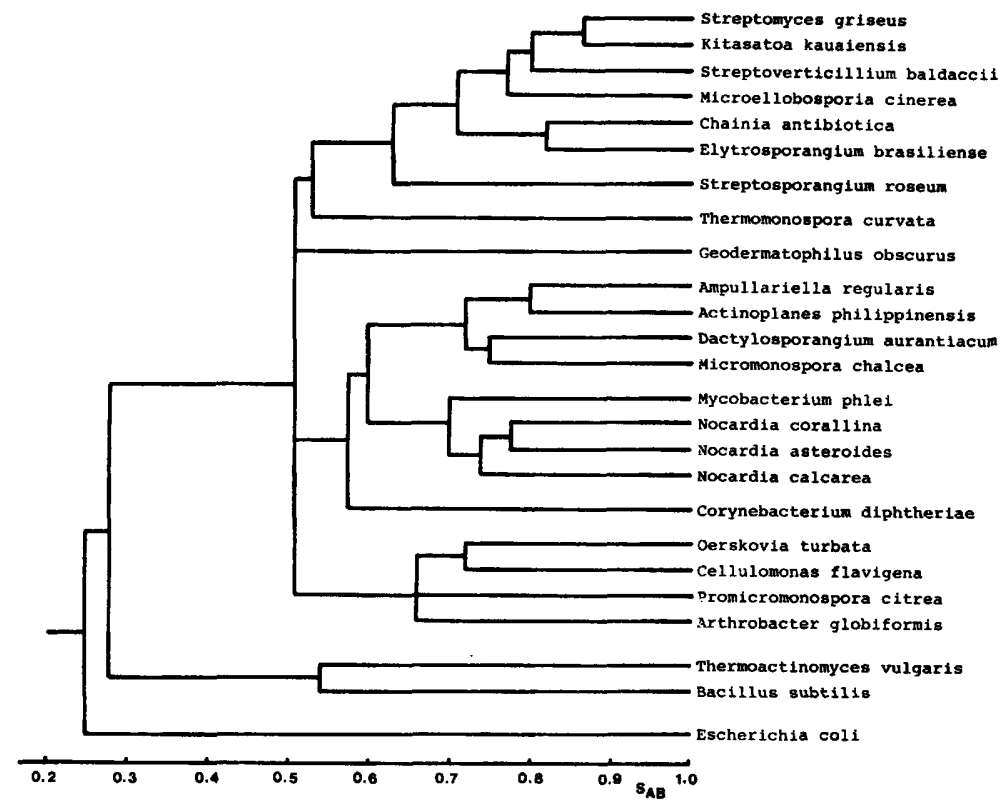

FIG. 1. Dendrogram of relationships among sporeforming and nonsporeforming members of the order Actinomycetales, coryneform bacteria, Bacillus subtilis, and Escherichia coli. This figure was constructed by average linkage clustering (between the merged groups) from the $S_{\mathrm{AB}}$ values given in Table 1 and those published previously $(15,17)$. Nocardia calcarea is identical to Rhodococcus erythropolis (M. Goodfellow, personal communication).

Nocardia asteroides DSM $43005^{1}$ is a member of the Mycobacterium-Nocardia-Rhodococcusline of descent (17) (Fig. 1) and shows high $S_{\mathrm{AB}}$ values when it is compared with Nocardia corallina, Nocardia calcarea, Brevibacterium ketoglutamicum, and Corynebacterium fascians ( $S_{\mathrm{AB}}, 0.73$ to 0.78 [unpublished data]); the $S_{\mathrm{AB}}$ value is slightly lower $\left(S_{\mathrm{AB}}, 0.69\right)$ when this strain is compared with Mycobacterium phlei.

The placement of Promicromonospora citrea in the enlarged Arthrobacter globiformis cluster (Fig. 1) is not surprising. Strains of this species and of cellulomonads and oerskovias are known to have similar phospholipids (10) and isoprenoid quinones (2). Indeed, the $S_{\mathrm{AB}}$ values indicate a closer degree of relatedness of Promicromonospora citrea to strains of Cellulomonas, Oerskovia, Arthrobacter, and Micrococcus than to members of other genera in this cluster (e.g., Microbacterium, Brevibacterium, and Actinomyces) (unpublished data). The peptidoglycan of Promicromonospora citrea contains alanine, glutamic acid, and lysine at a ratio of $4: 1: 1$, which is similar to the ratio found in arthrobacters and micrococci (13).

The phylogenetic structure of the order Actinomycetales is not always in accord with the classification of these organisms $(3,6)$. This is not surprising since Actinomycetales classification has been based almost solely on morpholog- ical characters and has been performed mainly for identification. Thus, the rather broad groups of organisms that are revealed by 16S rRNA analyses indicate the broad taxonomic value of several chemotaxonomic characteristics, including cell wall components, cellular fatty acid composition, and cellular sugars.

\section{ACKNOWLEDGMENTS}

We thank George Fox for interest in this work and for generating the dendrogram and calculating the $S_{\mathrm{AB}}$ values used.

This research was supported by the Deutsche Forschungsgemeinschaft.

\section{LITERATURE CITED}

1. Balch, W. E., G. E. Fox, L. J. Magrum, C. R. Woese, and R. S. Wolfe. 1979. Methanogens: reevaluation of a unique biological group. Microbiol. Rev. 43:260-296.

2. Collins, D., and D. Jones. 1981. Distribution of isoprenoid quinone structural types in bacteria and their taxonomic implications. Microbiol. Rev. 45:316-354.

3. Cross, T., and M. Goodfellow. 1973. Taxonomy and classification of the actinomycetes, p. 11-112. In G. Sykes and F. A. Skinner (ed.), Actinomycetales. Characteristics and practical importance. Academic Press, Inc., New York.

4. Fox, G. E., K. R. Pechman, and C. R. Woese. 1977. Comparative cataloging of $16 \mathrm{~S}$ ribosomal ribonucleic acid: molecular approach to procaryotic systematics. Int. J. Syst. Bacteriol. 27:44-57.

5. Fox, G. E., E. Stackebrandt, R. B. Hespell, J. Gibson, J. Maniloff, I. Dyer, R. S. Wolfe, W. Balch, R. Tanner, L. Magrum, L. B. Zablen, R. Blakemore, R. Gupta, K. R. 
Luehrsen, L. Bonen, B. J. Lewis, K. N. Chen, and C. R. Woese. 1980. The phylogeny of prokaryotes. Science 209:457-463.

6. Gottlieb, D. 1974. Actinomycetales, p. 657-861. In R. E. Buchanan and N. E. Gibbons (ed.), Bergey's manual of determinative bacteriology, 8th ed. The Williams \& Wilkins Co., Baltimore.

7. Kawamoto, I., O. Tetsuo, and N. Takashi. 1981. Cell wall composition of Micromonospora divoasterospora, Micromonospora sagamiensis, and related organisms. J. Bacteriol. 146:527-534.

8. Kroppenstedt, R. M. 1979. Chromatographische Identifzierung von Mikroorganismen, dargestellt am Beispiel der Aktinomyceten. Merck-Kontakte 2:12-21.

9. Kroppenstedt, R. M., F. Korn-Wendisch, V. J. Fowler, and E. Stackebrandt. 1981. Biochemical and molecular genetic evidence for a transfer of Actinoplanes armeniacus into the family Streptomycetaceae. Zentralbl. Bakteriol. Parasitenkd. Infektionskr. Hyg. Abt. 1 Orig. Reihe C 2:254-262.

10. Lechevalier, M.P., C. de Bievre, and H. Lechevalier. 1977. Chemotaxonomy of aerobic actinomycetes: phospholipid composition. Biochem. Syst. Ecol. 5:249-260.

11. Lechevalier, M. P., and H. Lechevalier. 1970. Chemical composition as a criterion in the classification of aerobic actinomycetes. Int. J. Syst. Bacteriol. 20:435-443.

12. Prauser, H. 1975. Host-phage relationships in nocardioform organisms, p. 266-284. In M. Goodfellow, G. H.
Brownell, and J. A. Serrano (ed.), The biology of Nocardia. Academic Press, Inc., New York.

13. Schleifer, K. H., and O. Kandler. 1972. Peptidoglycan types of bacterial cell walls and their taxonomic implications. Bacteriol. Rev. 36:407-477.

14. Stackebrandt, E., M. Häringer, and K. H. Schlelfer. 1980. Molecular genetic evidence for the transfer of Oerskovia species into the genus Cellulomonas. Arch. Microbiol. 127:179-185.

15. Stackebrandt, E., B. J. Lewis, and C. R. Woese. 1980. The phylogenetic structure of the coryneform group of bacteria. Zentralbl. Bakteriol. Parasitenkd. Infektionskr. Hyg. Abt. 1 Orig. Reihe C 2:137-149.

16. Stackebrandt, E., W. Ludwig, K. H. Schleifer, and H. J. Gross. 1981. Rapid cataloging of ribonuclease T1 resistant oligonucleotides from ribosomal RNAs for phylogenetic studies. J. Mol. Evol. 17:227-236.

17. Stackebrandt, E., and C. R. Woese. 1981. Towards a phylogeny of the actinomycetes and related organisms. Curr. Microbiol. 5:197-202.

18. Stackebrandt, E., and C. R. Woese. 1981. The evolution of prokaryotes. Symp. Soc. Gen. Microbiol. 32:1-31.

19. Stackebrandt, E., B. Wunner-Füssl, V. J. Fowler, and K. H. Schleifer. 1981. Molecular genetic relatedness of sporeforming members of the order Actinomycetales based on deoxyribonucleic acid homologies and ribosomal ribonucleic acid similarities. Int. J. Syst. Bacteriol. 31:420-431. 